\title{
Microfinance Market Diagnoses and Beneficiaries Impact - Case of Albania
}

\author{
Dr. Semiha Loca \\ "Marin Barleti" University, Faculty of Economics, Tirana, Albania \\ Email: semi.loca@gmail.com/bachelor.academic-quality@umb.edu.al \\ Forcim Kola PhD Candidate \\ "Aleksandër Moisiu" University, Faculty of Business, Durrës, Albania \\ Email: forcimkola@gmail.com \\ Prof.Dr. Bardhyl Ceku \\ "Aleksandër Moisiu" University, Faculty of Business, Durrës, Albania \\ Email: bardhi_ceku@yahoo.com \\ Rasim Zuferi, PhD Candidate \\ South and East European University, Tetovo, Macedonia (FYROM) \\ Email: r.zuferi@seeu.edu.mk
}

Doi:10.5901/ajis.2014.v3n6p205

\section{Abstract}

Small and micro entrepreneurs are often considered as a risky client group for banks, because they lack collateral or the capacity to convince banks that they are able to get and repay a business loan. The most important barrier to new business formation is the inability of entrepreneurs to acquire the capital necessary to start a business. Microfinance has proven to be an effective and powerful tool for poverty reduction. For this reason the microfinance policies intended to meet the needs of economically marginalized households and must carefully define the development challenge if they are to be effective. MFIs in Europe reported disbursing a total of 204,080 microloans (122,370 in the European Union) during 2011. In USA, for start-ups, receiving a microcredit increases their probability of survival by $44 \%$. About one fifth of the world's population lives in poverty, and approximately 2.5 billion adults lack a formal bank account according to some estimation. In developed countries as well, microfinance is increasingly being perceived as a potentially effective tool to counteract on the effects of the social and economic crisis. The aim of this research is to diagnose the attitude and perceptions towards microfinance in Albania, mainly those who are influenced in some way by MFIs, by providing evidence to analyze how microfinance service in Albania has contributed to poverty reduction, how and to what level the microfinance service has affected Albanian entrepreneurial activity, how these entrepreneurial business activities can benefit by using it. The methodology combines the application of both quantitative and qualitative tools. Questionnaires, Focus Group interviews and Semi-structured interviews are used to understand the situations that people face and how they use and perceive microfinance, how do they benefit from this sector, especially enterprises served by microfinance institutions in Albania.

Keywords: Microfinance sector, Poverty reduction, Perceptions, Beneficiaries impact, Albania.

\section{Introduction}

During the last years, microfinance has gained growing recognition as an effective tool in improving the quality of life and living standards of very poor people. This recognition has given rise to a movement that now has a global outreach and has penetrated in the remote rural areas, besides slums and towns.

The global loan portfolio amounted to USD 78 billion in 2011. Portfolio growth slowed to 15\% in 2011 against 25\% in 2009, but there has been a nearly $25 \%$ annual growth in Africa and Latin America since 2009. The top 100 institutions still represent $80 \%$ of the total lending portfolio -USD 61 billion - and 75\% of the borrowers served at a global level in 2011. Microenterprise business lending represents $60 \%$ of total lending, and $80 \%$ of active borrowers. 
MFIs in Europe, only in 2011 has reported disbursing a total of 204,080 microloans (122,370 in the European Union) amounting to a total volume of around EUR 1,047 million (EUR 872 million in the EU). The average reported loan size in 2011 is EUR 5,135 in Europe, and EUR 7,129 in the EU. The average interest rate is 11\%, ranging from 4\% to more than $30 \%$ in some Balkan countries, and the average loan term is 35 months, ranging from 14 to 60 months. $22 \%$ of microfinance institutions are NGOs or foundations, $20 \%$ are non-bank financial institutions (NBFIs), and $14 \%$ are microfinance associations. Respectively $72 \%$ and $42 \%$ of microfinance institutions indicate job creation and social inclusion and poverty reduction as one of their missions. ${ }^{1}$ Based on these facts and figures, the research highlights the importance for the new and innovative business entrepreneurs to lead large business environment.

Table 1.1 Gross loan portfolio of Albanian MFIs²

\begin{tabular}{|l|c|c|c|c|c|c|c|c|}
\hline \multicolumn{7}{|c|}{ Gross Loan Portfolio } \\
\hline MFIs & $\mathbf{2 0 0 5}$ & $\mathbf{2 0 0 6}$ & $\mathbf{2 0 0 7}$ & $\mathbf{2 0 0 8}$ & $\mathbf{2 0 0 9}$ & $\mathbf{2 0 1 0}$ & $\mathbf{2 0 1 1}$ & $\mathbf{2 0 1 2}$ \\
\hline FAF-DC & $12,157,757$ & $14,508,865$ & $16,563,293$ & $16,441,313$ & $16,068,681$ & $18,496,020$ & $21,009,663$ & $21,585,482$ \\
\hline ASC Union & $11,616,044$ & $17,494,828$ & $24,079,653$ & $40,501,796$ & $40,851,173$ & $38,489,705$ & $35,547,681$ & $35,857,479$ \\
\hline BESA & $23,068,356$ & $29,094,019$ & $37,245,305$ & $41,316,674$ & $43,556,028$ & $42,307,626$ & $41,467,853$ & $47,280,837$ \\
\hline NOA & $13,999,345$ & $25,490,954$ & $36,511,760$ & $42,424,368$ & $43,357,186$ & $39,773,373$ & & \\
\hline VisionFund & & & $1,653,565$ & $1,320,349$ & $2,046,318$ & $2,023,592$ & $2,045,368$ & $2,264,384$ \\
\hline Total in USD & $\mathbf{6 0 , 8 4 1 , 5 0 1}$ & $\mathbf{8 6 , 5 8 8 , 6 6 5}$ & $\mathbf{1 1 6 , 0 5 3 , 5 7 7}$ & $\mathbf{1 4 2 , 0 0 4 , 5 0 0}$ & $\mathbf{1 4 5 , 8 7 9 , 3 8 6}$ & $\mathbf{1 4 1 , 0 9 0 , 3 1 5}$ & $\mathbf{1 0 0 , 0 7 0 , 5 6 5}$ & $\mathbf{1 0 6 , 9 8 8 , 1 8 2}$ \\
\hline
\end{tabular}

A number of studies have been carried out on the impact, perceptions and attitude of microfinance in Albania. Kola (2010) is focused on the microcredit contribution on social wellbeing in Albania. This study brings facts/figures shedding light on some issues: becoming a client of microcredit companies bring positive changes in the living standards of microcredit program participants and in their communities at large; being Microfinance Institutions client is associated with greater acquisition of land relative to non-clients, which can be taken as significant evidence of positive impact. In this study there is strong evidence of positive impact on the multiple dimensions of household income and enterprise performance.

Kola and Korsita (2010) are more interested in the effects on social and economic development. The results of their Quantitative Impact Survey illustrate the great impact of microfinance on enabling access to microfinancial services to the low-income people. There is strongly evidence the positive impact of microfinance products on income is in close relationship with the broader macro-economic environmental indicators of Albania.

Kola, Korsita and Abazi (2011) underline the positive economic and social effect on entrepreneurial activities. Other articles focused on the mechanism reducing poverty or on the ability of microfinance to reach the poor and vulnerable.

In Albania, as well as in other countries a great number of studies have been carried out on the impact of microfinance illustrating many relevant aspects of our research.

Sebstad and Walsh (1991) have also underscored the positive impact of microcredit on microenterprise sales. Mosley (1996) conducted a study in Bolivia noted that respondents enterprise income increased by $91 \%, 39 \%$ borrowers employed after participation and 26\% used loan for new technology - mostly sewing machines. Kamal (1999) measured the impact of ASA's (Association for Social Advancement) microcredit programs in Bangladesh, noted that $90.42 \%$ of the sampled respondents reported an increase in business capital after participation.

In his study on Grameen Bank's microcredit clients in Bangladesh Latifee (2003) noted that the effect of Grameen loan on reducing unemployment rate among clients and on their households were impressive. He also mentions that about $90 \%$ of borrowers reported an improvement in standard of living.

Elizabeth Dunn conducted an impact study on 'Local Initiative (Microfinance) Project II' clients in 2005, in Bosnia and Herzegovina. The findings of her study indicated that microcredit had a significant positive impact on household income, employment, business investment, business registration and post-war transition.

Experience and evidence shows that microcredit has a positive effect on the socio-economic conditions of the clients, their households and their microenterprise (Mamun, Wahab and Malarvizhi, 2010).

\footnotetext{
1 The Microfinance Barometer 2013 - $4^{\text {th }}$ Edition

2 http://www.mixmarket.org/mfi/country/Albania, September 2013
} 
Almost all these studies seems to bring a very admirable view of microfinance impact, undertaking and providing an excellent picture of the quality of MFIs lending as well as some quantitative information related to employment creation and earnings of enterprises. MFIs activities are providing significant return to their clients meeting the objective of the microfinance institutions both in terms of livelihood improvements, poverty reduction, job creation, import substitutions and technology transfer.

\section{Methodology}

This research has been done in order to assess, on a national scale, the development impact of microfinance in relation to different product designs and delivery systems in various parts of Albania aiming to measure the effect of microfinance in entrepreneurial activities.

The primary objective of this research was to find out how micro-lending practices affect entrepreneurial activity in Albania taking into consideration many business activities and measuring to them some attributes before and after taking the loan from any microfinance institution in the contry.

The key research questions addressed during the study include:

$\nabla$ Does microfinance contribute to enterprise growth?

$\nabla$ How does it leads clients to diversify economic activity?

$\nabla$ Does microfinance increases enterprise income?

$\nabla$ Does microfinance over a period of years increases enterprise assets?

$\nabla$ Does microfinance leads to changes in business practices associated with increased profitability?

These basic questions were translated into hypothesis linking input variables (MFI services) and moderating variables (enterprise client characteristics, programme characteristics and others) to ascertain the impact on entrepreneurial activity in Albania.

\subsection{Sample design}

The selection of the survey sample was done by following best practices first geographically clustering the clients. The survey revealed that geographical differentiation (rural, urban and peri-urban) was the most appropriate form of clustering. The final sampled numbers closely approximated the proportions of clients in terms of gender and percentage of borrowers and savers.

For this survey a total of 150 clients of Microfinance Institutions in Albania were interviewed during September 2013.

The small group interview sessions were conducted with clients who were stratified and segmented along gender lines to identify any gender differences in outcome.

\subsection{Data Collection and Analysis;}

The study combined the application of both quantitative and qualitative tools including questionnaire on different indicators addressed to beneficiaries and other stakeholders. Qualitative information was collected through Focus Group Interviews and Semi-structured interviews to understand the situations that people face and how they use and perceive microfinance, especially enterprises served by microfinance sector in Albania.

The quantitative data of sample enterprises were analyzed to find out percentages, averages and frequencies of various indicators. 


\section{Demographic Data of Microfinance Clients}

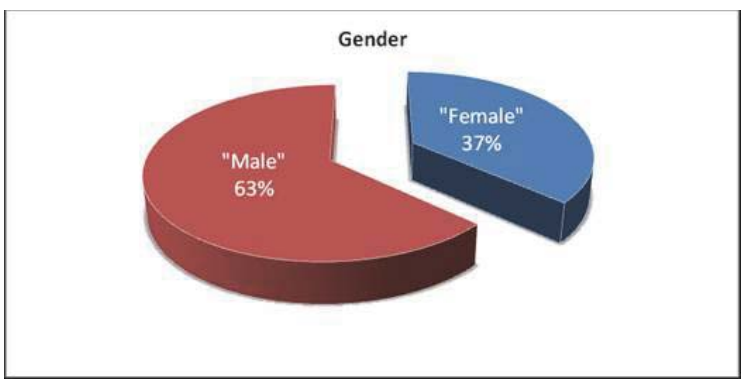

Chart 3.1 Classification of clients based on gender

The distribution of sample respondents according to gender in Albania is shown in chart 3.1. Of the total 150 respondents 55 are Female occupying $36.7 \%$ and 95 are Male category occupying $63.3 \%$. It is clear that the majority of the respondents are male.

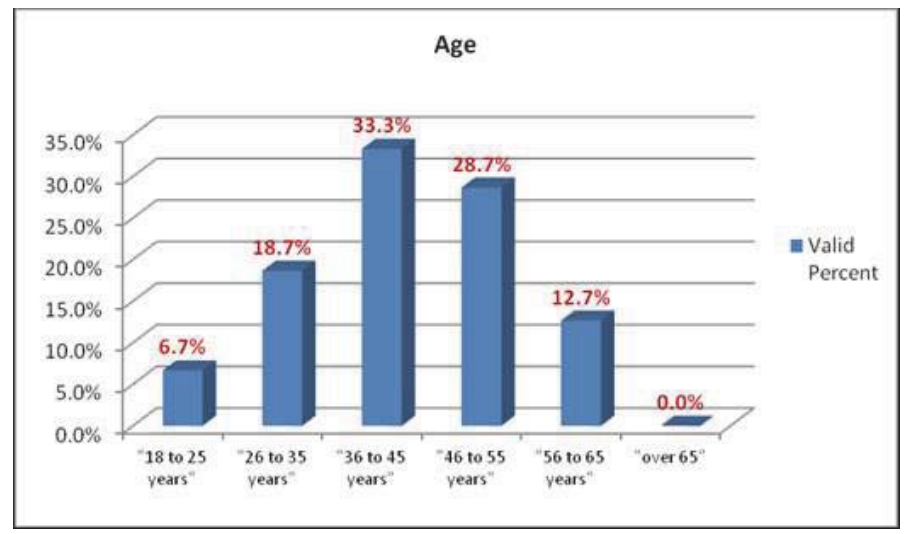

Chart 3.2 Classification of clients based on age

Chart 3.2, represents the distribution of respondents based on age. Respondents belonging to the age group of 18-25 years are found 10 forms $6.7 \%$ followed by 28 respondents occupying $18.7 \%$ in the age group of 26-35. 50 respondents $33.3 \%$ from the age group between $36-45,43$ respondents constituting $28.7 \%$ in the age group of $46-55$ years. 19 respondents occupying $12.7 \%$ are in the age group of $56-65$ years, and 0 respondents occupying $0.0 \%$ are above 65 years.

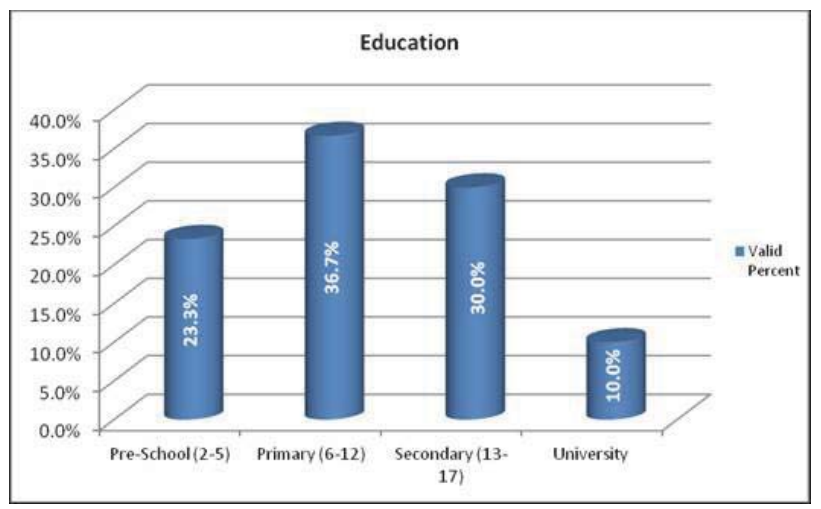

Chart 3.3 Classification of clients based on educational qualification 
Chart 3.3 indicates the number of respondents on the basis of educational background. The research has analyzed 35 respondents consisting of $23.3 \%$ with Pre-School qualification (2-5), 55 respondents occupying $36.7 \%$ with Primary (612), followed by 45 respondents with $30.0 \%$ with Secondary (13-17), and 15 respondents occupying $10.0 \%$ with university education.

According to the data provided by the sample, we found that the majority of microfinance clients belong to the group of "Primary (6-12)" education, with the lowest percentage in the education group with a University Degree. These facts show that microfinance in Albania is focused on low educated people, helping them realize their specific objectives.

In France, for example, the beneficiaries of personal and professional microcredit often share the same characteristics. In general, they are under 40 years of age with minimal qualifications. Moreover, beneficiaries of professional microcredit are essentially male (62\%), with a secondary or higher education diploma (43\%) and mostly unemployed (65\%). In this case, microcredit is a stepping-stone on the path to employment. On the other hand beneficiaries of personal microcredit are essentially employed (52\%). ${ }^{3}$

To increase access to financial services worldwide, microfinance is using innovative products and delivery channels, such as mobile banking, and working to increase the capacities of service providers.

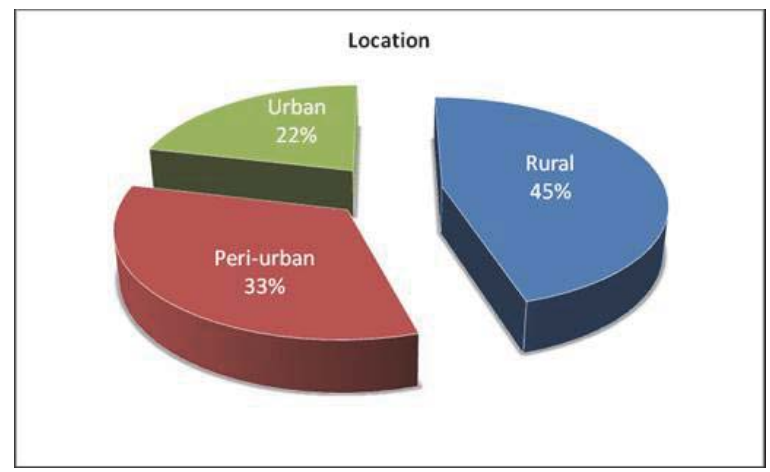

Chart 3.4 Classification of clients based on location

Chart 3.4, indicates the distribution of respondents based on location; 68 respondents (45.3\%) belong to rural area, 50 respondents (33.3\%) belong to peri-urban area and 32 respondents (21.3\%) belong to urban area.

The data show that the microfinance market in Albania is mainly spread out in the rural areas of the country correlating with the same target group of microfinance worldwide.

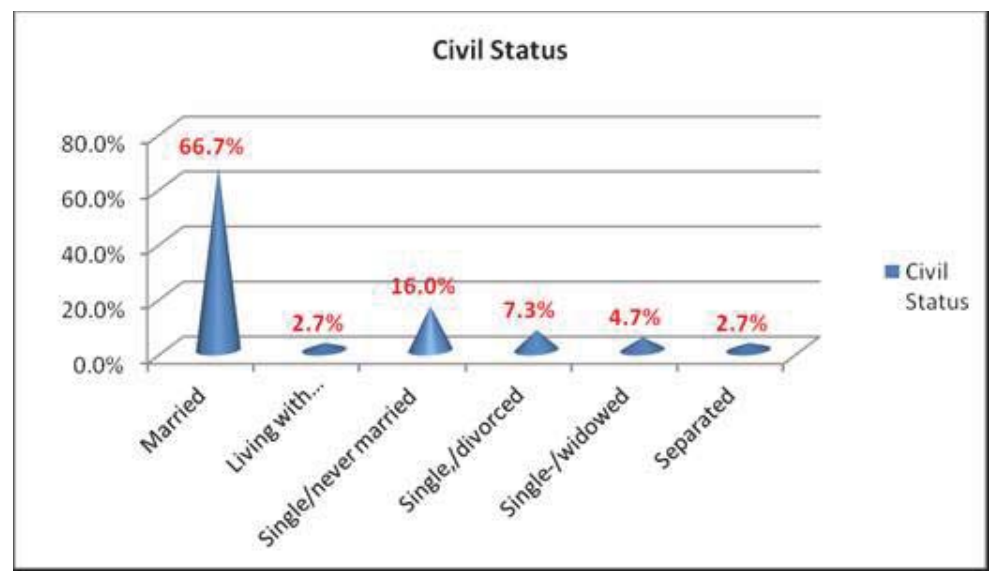

Chart 3.5 Classification of clients based on civil status

3 The Microfinance Barometer 2012 - $3^{\text {th }}$ Edition 
Chart 3.5, reveals that 100 respondents occupying $66.7 \%$ belong to the Married category, 4 respondents occupying $2.7 \%$ belong to the Living with companion category, 24 respondents occupying $16.0 \%$ belong to the Single/never married category, 11 respondents occupying $7.3 \%$ belong to the Single/divorced category, 7 respondents occupying $4.7 \%$ belong to the Single/widowed category and 4 respondents amounting to $2.7 \%$ belong to Separated category.

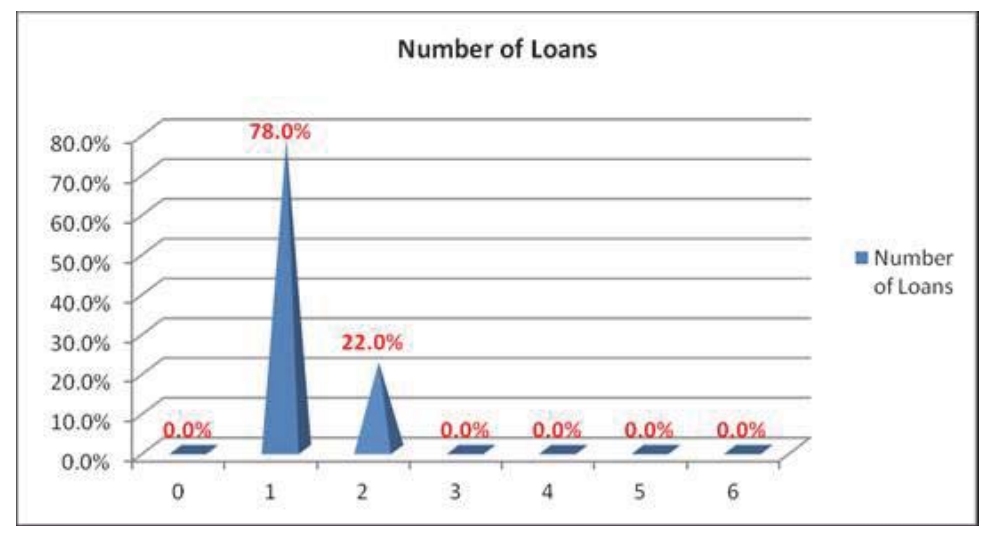

Chart 3.6 Classification of clients based on number of loans

Chart 3.6 indicates the number of respondents on the basis of the number of loans, 0 respondents occupying (0.0\%) belongs to the category of zero loans, out of the total 150 respondents considered for the research.

This is followed by 117 respondents (78.0\%) belonging to the group of one loan and 33 respondents $(22.0 \%)$ belonging to the group of two loans.

\section{Testing of the Research Hypotheses}
Hypotheses for the enterprise level
Being client of microfinance services:
Hypothesis $\mathrm{E}_{1}$ contributes to enterprise growth.
Hypothesis $\mathrm{E}_{2}$ leads clients to diversify economic activity.
Hypothesis $\mathrm{E}_{3}$ increases enterprise income.
Hypothesis $\mathrm{E}_{4}$ over a period of years increases enterprise assets.
Hypothesis $E_{5}$ leads to changes in business practices associated with increased profitability.

With microfinance support, clients have either started new or expanded existing enterprises which not only provided better employment opportunities but also increased enterprise income.

It is widely accepted that for an enterprise becoming a microfinance client leads to higher employee salaries, job creation, increases enterprise assets, and many other improvements. But let us see whether if this is true for microfinance clients in Albania.

\subsection{Does microfinance contribute to enterprise growth?}

\subsubsection{The number of employees;}

The number of employees before and after taking a loan from MFIs has been recorded for 10 enterprises as in the table below:

\begin{tabular}{l|c|c|c|c|c|c|c|c|c|c} 
Business activities & 1 & 2 & 3 & 4 & 5 & 6 & 7 & 8 & 9 & 10 \\
\hline Before loan & 4 & 3 & 12 & 2 & 4 & 2 & 5 & 3 & 4 & 3 \\
\hline After loan & 4 & 5 & 16 & 5 & 3 & 4 & 7 & 4 & 7 & 3
\end{tabular}

Can the MFIs crediting be judged to be a success in job creation? Let's test at 5 per cent level of significance, using paired t-test. 
Paired $t$-test is a way to compare two related samples, involving small values of $n$ that does not require the variances of the two populations to be equal, but the assumption that the two populations are normal must continue to apply.

For a paired $t$-test, it is necessary that the observations in the two samples be collected in the form of what is called matched pairs i.e., "each observation in the one sample must be paired with an observation in the other sample in such a manner that these observations are somehow "matched" or related, in an attempt to eliminate extraneous factors which are not of interest in test. Such a test is generally considered appropriate in a before-and-after-loan study.

Using the Paired $t$-test calculations made with STATA we can confirm if there is a difference between number of employees before and after the loan or if the lending practice has been efficient or not in job creation or increasing employment.

Table 4.1 Hypotheses testing for comparing two related samples of employee number

Paired T-Test of mean difference $=0$ versus not $=0$
\begin{tabular}{|c|c|c|c|c|c|c|c|c|c|}
\hline \multicolumn{1}{|c|}{ Alternative hypothesis: true mean of differences is not equal to 0 } \\
\hline $\mathrm{N}$ & Mean & StDev & SE Mean & Corr & $95 \%$ Conf Interval & $\mathrm{t}$ & df & $\mathrm{p}$-value & Alt Hypothesis \\
\hline 10 & $-1,6000$ & 1,5776 & 0,4989 & 0,9294 & {$[-2,7286 ;-0,4714]$} & $-3,2071$ & 9 & 0,0107 & Accept \\
\hline
\end{tabular}

As shown in the table above, we have to reject the null hypotheses, concluding that there is a difference in the number of employees before and after the loan or that the lending practice has been efficient for enterprises served in job creation leading to increased employment.

\subsubsection{The average salary of employees;}

Let's see the impact of lending practices of MFIs in average salary of employees using hypothesis testing for comparing two related samples;

Average salary of employees before and after the loan has been recorded for 10 enterprise activities as shown in the table below; Using the Paired $t$-test calculations made with STATA we can conclude if there is a difference between average salary of employees before and after the loan, or if the lending practice has been efficient or not in increasing employee salaries.

\begin{tabular}{l|c|c|c|c|c|c|c|c|c|c} 
Business activities & 1 & 2 & 3 & 4 & 5 & 6 & 7 & 8 & 9 & 10 \\
\hline Before loan & 35000 & 20000 & 45000 & 15000 & 25000 & 23000 & 18000 & 25000 & 25000 & 15000 \\
\hline After loan & 40000 & 25000 & 50000 & 25000 & 25000 & 20000 & 20000 & 30000 & 35000 & 20000
\end{tabular}

Table 4.2 Hypotheses testing for comparing two related samples of employee salary

\begin{tabular}{|c|c|c|c|c|c|c|c|c|c|}
\hline \multicolumn{10}{|c|}{ Paired T-Test of mean difference $=0$ versus not $=0$} \\
\hline \multicolumn{10}{|c|}{ Alternative hypothesis: true mean of differences is not equal to 0} \\
\hline $\mathrm{N}$ & Mean & StDev & SE Mean & Corr & 95\% Conflnterval & $\mathrm{t}$ & $\mathrm{df}$ & p-value & Alt Hypothesis \\
\hline 10 & $-4400,0$ & 4005,55 & 1266,66 & 0,9155 & {$[-7265,39 ;-1534,60]$} & $-3,4737$ & 9 & 0,0070 & Accept \\
\hline
\end{tabular}

As shown in the table above, we have to reject the null hypotheses, concluding that there is a difference in average salary of employees before and after the loan or that the MFls lending practice has been efficient in increasing employee salaries for enterprises served.

\subsubsection{The number of suppliers;}

It has been also recorded the number of suppliers before and after the loan for 10 business activities credited by MFIs, as they are shown in the table below; Using the Paired $t$-test calculations made with STATA we can test the hypotheses for comparing two related samples of the number of suppliers for MFIs clients before and after taking the loan, or if the MFIs lending process has been efficient or not in increasing the number of suppliers of client business activities, contributing in this way in the value chain process. 


\begin{tabular}{l|c|c|c|c|c|c|c|c|c|c} 
Business activities & 1 & 2 & 3 & 4 & 5 & 6 & 7 & 8 & 9 & 10 \\
\hline Before loan & 13 & 9 & 6 & 4 & 7 & 8 & 5 & 3 & 20 & 11 \\
\hline After loan & 16 & 12 & 5 & 6 & 11 & 7 & 7 & 3 & 24 & 13
\end{tabular}

Table 4.3 Hypotheses testing for comparing two related samples of the number of suppliers

\begin{tabular}{|c|c|c|c|c|c|c|c|c|c|}
\hline \\
\hline \multicolumn{10}{|c|}{$\begin{array}{l}\text { Paired T-Test of mean difference }=0 \text { versus not }=0 \\
\text { Alternative hypothesis: true mean of differences is not equal to } 0\end{array}$} \\
\hline $\mathrm{N}$ & Mean & StDev & SE Mean & Corr & $95 \%$ Conf Interval & $\mathrm{t}$ & df & $p$-value & Alt Hypothesis \\
\hline 10 & $-1,8000$ & 1,8738 & 0,5925 & 0,9672 & {$[-3,1404 ;-0,4596]$} & $-3,0377$ & 9 & 0,0141 & Accept \\
\hline
\end{tabular}

As shown in the table above, we have to reject the null hypotheses, concluding that there is a difference in the number of suppliers before and after the loan or that the lending process of MFIs has been successful in increasing the number of suppliers for enterprises served thus expanding the levels of the value chain.

\subsubsection{The average value of purchases for each supplier;}

Also trying to measure the effect of crediting, the average value of purchases from each supplier before and after the loan for 10 business activities credited by MFIs, has been recorded as shown in the table below; Using the Paired $t$-test calculations made with STATA we can test the hypotheses for comparing two related samples of the average value of purchases from each supplier for MFIs clients before and after taking the loan, or if the MFIs lending process has been efficient in increasing the average value of purchases from each supplier of client business activities, contributing in this way to the value chain process, derived from the quantity of purchases from each supplier.

\begin{tabular}{l|c|c|c|c|c|c|c|c|c|c} 
Business activities & 1 & 2 & 3 & 4 & 5 & 6 & 7 & 8 & 9 & 10 \\
\hline Before loan & 35000 & 55000 & 650000 & 30000 & 44000 & 40000 & 95000 & 25000 & 60000 & 25000 \\
\hline After loan & 45000 & 65000 & 750000 & 35000 & 45000 & 35000 & 120000 & 40000 & 85000 & 45000
\end{tabular}

Table 4.4 Hypotheses testing for comparing two related samples of the purchases for each supplier

\begin{tabular}{|c|c|c|c|c|c|c|c|c|c|}
\hline \multicolumn{2}{|c|}{ Paired T-Test of mean difference $=0$ versus not $=0$} \\
\hline Alternative hypothesis: true mean of differences is not equal to 0 \\
\hline $\mathrm{N}$ & Mean & StDev & SE Mean & Corr & $95 \%$ Conf Interval & t & df & p-value & Alt Hypothesis \\
\hline 10 & $-20600,0$ & 29594,29 & 9358,53 & 0,9992 & {$[-41770,48 ; 570,48]$} & $-2,2012$ & 9 & 0,0552 & Accept \\
\hline
\end{tabular}

As shown in the table above, we have to reject the null hypotheses, concluding that there is a difference in the average value of purchases for each supplier before and after the loan or that the lending process of MFIs has been efficient in increasing the average value of purchases for each supplier of the enterprises served.

\subsubsection{The number of clients;}

For the purpose of this study there has also been recorded the number of clients before and after the loan for 10 business activities credited by MFIs, as they are shown in the table below; Using the Paired $t$-test calculations made with STATA we can test the hypotheses for comparing two related samples of the number of clients for MFIs clients before and after taking the loan, or if the MFIs lending process has been efficient or not in increasing the number of clients of business activities, contributing in this way to the value chain process by increasing the number of clients.

\begin{tabular}{c|c|c|c|c|c|c|c|c|c|c} 
Business activities & 1 & 2 & 3 & 4 & 5 & 6 & 7 & 8 & 9 & 10 \\
\hline Before loan & 35 & 95 & 45 & 10 & 120 & 60 & 55 & 10 & 15 & 30 \\
\hline After loan & 50 & 150 & 50 & 20 & 150 & 120 & 110 & 15 & 30 & 35
\end{tabular}

Table 4.5 Hypotheses testing for comparing two related samples of the number of clients

\begin{tabular}{|c|c|c|c|c|c|c|c|c|c|}
\hline \multirow{2}{*}{\multicolumn{10}{|c|}{ Paired T-Test of mean difference $=0$ versus not $=0$}} \\
\hline & & & & & & & & & \\
\hline $\mathrm{N}$ & Mean & StDev & SE Mean & Corr & 95\% Conf Interval & $t$ & $\mathrm{df}$ & $p$-value & Alt Hypothesis \\
\hline 10 & $-25,5000$ & 22,7852 & 7,2053 & 0,9423 & {$[-41,7996 ;-9,2004]$} & $-3,5391$ & 9 & 0,0063 & Accept \\
\hline
\end{tabular}


As shown in the table above, we have to reject the null hypotheses, concluding that there is a difference in the number of clients before and after the loan or that the lending process of MFIs has been efficient in increasing the number of clients of the enterprises served.

\subsubsection{The average value of sales for each client;}

In the process of measuring the effect of crediting, there has been recorded the average value of sales for each client before and after the loan for 10 business activities credited by MFIs, as they are shown in the table below; Using the Paired $t$-test calculations made with STATA we can test the hypotheses for comparing two related samples of the average value of sales for each client for MFIs clients before and after taking the loan, or if the MFIs lending process has been efficient or not in increasing the average value of sales for each client business activities, contributing in this way to the value chain process, derived from the quantity of sales to each client.

\begin{tabular}{l|c|c|c|c|c|c|c|c|c|c} 
Business activities & 1 & 2 & 3 & 4 & 5 & 6 & 7 & 8 & 9 & 10 \\
\hline Before loan & 15000 & 25000 & 2500000 & 35000 & 10000 & 30000 & 3500 & 10000 & 100000 & 2500 \\
\hline After loan & 20000 & 35000 & 3000000 & 40000 & 15000 & 25000 & 4500 & 12000 & 150000 & 4500
\end{tabular}

Table 4.6 Hypotheses testing for comparing two related samples of the average value of sales for each client

\begin{tabular}{|c|c|c|c|c|c|c|c|c|c|}
\hline \multicolumn{10}{|c|}{ Paired T-Test of mean difference $=0$ versus not $=0$} \\
\hline \multicolumn{10}{|c|}{ Alternative hypothesis: true mean of differences is not equal to 0} \\
\hline $\mathrm{N}$ & Mean & StDev & SE Mean & Corr & 95\% Conf Interval & $\mathrm{t}$ & $\mathrm{df}$ & $p$-value & Alt Hypothesis \\
\hline 10 & $-57500,0$ & 156221,53 & 49401,58 & 0,9999 & {$[-169254,15 ; 54254,15]$} & $-1,1639$ & 9 & 0,2744 & Reject \\
\hline
\end{tabular}

As shown in the table above, we have to accept the null hypotheses, concluding that there is not a difference in the average value of sales for each client before and after the loan or that the lending process of MFIs has not been efficient in increasing the average value of sales for each client of the enterprises served.

\subsubsection{The annual production / sales;}

As part of the data of this research study there has also been recorded the annual production / sales before and after the loan for 10 business activities credited by MFIs, as they are shown in the table below; Using the Paired $t$-test calculations made with STATA we can test the hypotheses for comparing two related samples of the annual production / sales for MFIs clients before and after taking the loan, or if the MFIs lending process has been efficient or not in increasing the annual production / sales of business activities, contributing in this way to the value chain process.

\begin{tabular}{l|c|c|c|c|c|c|c|c|c|c} 
Business activities & 1 & 2 & 3 & 4 & 5 & 6 & 7 & 8 & 9 & 10 \\
\hline Before loan & 30000 & 3000000 & 5500000 & 150000 & 400000 & 350000 & 200000 & 55000 & 6000000 & 50000 \\
\hline After loan & 50000 & 4000000 & 7500000 & 200000 & 500000 & 450000 & 500000 & 75000 & 10000000 & 65000
\end{tabular}

Table 4.7 Hypotheses testing for comparing two related samples of the annual production / sales

\begin{tabular}{|c|c|c|c|c|c|c|c|c|c|}
\hline \multicolumn{10}{|c|}{ Paired T-Test of mean difference $=0$ versus not $=0$} \\
\hline \multicolumn{10}{|c|}{ Alternative hypothesis: true mean of differences is not equal to 0} \\
\hline $\mathrm{N}$ & Mean & StDev & SE Mean & Corr & 95\% Conf Interval & $\mathrm{t}$ & df & $p$-value & Alt Hypothesis \\
\hline 10 & $-760500,00$ & 1305114,83 & 412713,54 & 0,9922 & {$[-1694122,90 ; 173122,90]$} & $-1,8427$ & 9 & 0,0985 & Accept \\
\hline
\end{tabular}

As shown in the table above, we have to reject the null hypotheses, concluding that there is a difference in the annual production / sales before and after the loan or that the lending process of MFls has been successful in increasing the annual production / sales of enterprises served. 


\subsection{How does it lead clients to diversify economic activity?}

\subsubsection{The number of products / services;}

There has also been recorded the number of products and services before and after the loan for 10 business activities credited by MFIs, as they are shown in the table below; Using the Paired $t$-test calculations made with STATA we can test the hypotheses for comparing two related samples of the number of products and services for MFIs business clients before and after taking the loan, or if the MFIs lending process has been efficient or not in increasing the number of products and services of business activities.

\begin{tabular}{l|c|c|c|c|c|c|c|c|c|c} 
Business activities & 1 & 2 & 3 & 4 & 5 & 6 & 7 & 8 & 9 & 10 \\
\hline Before loan & 4 & 3 & 2 & 1 & 0 & 7 & 12 & 8 & 5 & 9 \\
\hline After loan & 5 & 6 & 2 & 2 & 1 & 9 & 15 & 8 & 7 & 11
\end{tabular}

Table 4.8 Hypotheses testing for comparing two related samples of the number of products and services

\begin{tabular}{|c|c|c|c|c|c|c|c|c|c|}
\hline \multicolumn{10}{|c|}{ Paired T-Test of mean difference $=0$ versus not $=0$} \\
\hline & hative hyp & hesis: tr & mean of $d$ & rences $\mathrm{i}$ & not equal to 0 & & & & \\
\hline $\mathrm{N}$ & Mean & StDev & SE Mean & Corr & 95\% Conf Interval & $\mathrm{t}$ & $\mathrm{df}$ & $p$-value & Alt Hypothesis \\
\hline 10 & $-1,5000$ & 1,0801 & 0,3416 & 0,9748 & {$[-2,2727 ;-0,7273]$} & $-4,3916$ & 9 & 0,0017 & Accept \\
\hline
\end{tabular}

As shown in the table above, we have to reject the null hypotheses, concluding that there is a difference in the number of products and services before and after the loan or that the lending process of MFIs has been efficient in increasing the number of products and services of enterprises served.

\subsubsection{The number of districts offering the business activities;}

For the purpose of this study there has also been recorded the number of districts offering the business activities before and after the loan for 10 business activities credited by MFIs, as they are shown in the table below; Using the Paired $t$ test calculations made with STATA we can test the hypotheses for comparing two related samples of the number of districts offering the business activities for MFIs clients before and after taking the loan, or if the MFIs lending process has been efficient or not in increasing the number of districts offering the business activities of MFIs business clients, contributing in this way in the value chain process by increasing the number of districts offering the business activities expanding so the area of doing business for MFIs clients.

\begin{tabular}{l|c|c|c|c|c|c|c|c|c|c} 
Business activities & 1 & 2 & 3 & 4 & 5 & 6 & 7 & 8 & 9 & 10 \\
\hline Before loan & 0 & 3 & 1 & 1 & 1 & 3 & 1 & 3 & 2 & 2 \\
\hline After loan & 1 & 3 & 1 & 2 & 1 & 2 & 1 & 3 & 5 & 2
\end{tabular}

Table 4.9 Hypotheses testing for comparing two related samples of the number of districts operating

\begin{tabular}{|c|c|c|c|c|c|c|c|c|c|}
\hline \multicolumn{10}{|c|}{ Paired T-Test of mean difference $=0$ versus not $=0$} \\
\hline \multicolumn{10}{|c|}{ Alternative hypothesis: true mean of differences is not equal to 0} \\
\hline $\mathrm{N}$ & Mean & StDev & SE Mean & Corr & 95\% Conf Interval & $\mathrm{t}$ & $\mathrm{df}$ & $\mathrm{p}$-value & Alt Hypothesis \\
\hline 10 & $-0,400$ & 1,0750 & 0,3399 & 0,5951 & {$[-1,1690 ; 0,3690]$} & $-1,1767$ & 9 & 0,2695 & Reject \\
\hline
\end{tabular}

As shown in the table above, we have to accept the null hypotheses, concluding that there is not any difference in the number of districts offering the business activities before and after the loan or that the lending process of MFIs has not been efficient in increasing the number of districts offering the business activities of enterprises served, not contributing in expanding the business area for the MFIs clients. 


\subsection{Does microfinance increases enterprise income?}

\subsubsection{The average daily revenues;}

As part of the data of this study there has also been recorded the average daily revenues before and after the loan for 10 business activities credited by MFIs, as they are shown in the table below; Using the Paired $t$-test calculations made with STATA we can test the hypotheses for comparing two related samples of the average daily revenues for MFIs clients before and after taking the loan, or if the MFIs lending process has been efficient or not in increasing the average daily revenues of business activities, contributing in this way to increasing the business activities.

\begin{tabular}{l|c|c|c|c|c|c|c|c|c|c} 
Business activities & 1 & 2 & 3 & 4 & 5 & 6 & 7 & 8 & 9 & 10 \\
\hline Before loan & 15000 & 10000 & 20000 & 5000 & 2500 & 12000 & 23000 & 2200 & 15000 & 30000 \\
\hline After loan & 20000 & 10000 & 25000 & 12000 & 3500 & 20000 & 30000 & 3000 & 25000 & 35000
\end{tabular}

Table 4.10 Hypotheses testing for comparing two related samples of the average daily revenues

\begin{tabular}{|c|c|c|c|c|c|c|c|c|c|}
\hline \multicolumn{10}{|c|}{ Paired T-Test of mean difference $=0$ versus not $=0$} \\
\hline Alte & lative hypo & esis: true & ean of diffe & nces is $n$ & equal to 0 & & & & \\
\hline $\mathrm{N}$ & Mean & StDev & SE Mean & Corr & 95\% Conf Interval & $\mathrm{t}$ & $\mathrm{df}$ & $p$-value & Alt Hypothesis \\
\hline 10 & $-4880,00$ & 3341,58 & 1056,70 & 0,9605 & {$[-7270,42 ;-2489,57]$} & $-4,6181$ & 9 & 0,0013 & Accept \\
\hline
\end{tabular}

As shown in the table above, we have to reject the null hypotheses, concluding that there is a difference in the average daily revenues before and after the loan or that the lending process of MFIs has been successful in increasing the average daily revenues of the enterprises served.

\subsubsection{The average monthly revenues;}

The data gathered for this study are also part of the average monthly revenues before and after the loan for 10 business activities credited by MFIs, as they are shown in the table below; Using the Paired $t$-test calculations made with STATA we can test the hypotheses for comparing two related samples of the average monthly revenues for MFls clients before and after taking the loan, or if the MFls lending process has been efficient or not in increasing the average monthly revenues of business activities, contributing in this way to increasing the business activities.

\begin{tabular}{l|c|c|c|c|c|c|c|c|c|c} 
Business activities & 1 & 2 & 3 & 4 & 5 & 6 & 7 & 8 & 9 & 10 \\
\hline Before loan & 400000 & 280000 & 650000 & 120000 & 70000 & 350000 & 600000 & 65000 & 350000 & 700000 \\
\hline After loan & 500000 & 300000 & 850000 & 350000 & 80000 & 400000 & 750000 & 80000 & 550000 & 850000
\end{tabular}

Table 4.11 Hypotheses testing for comparing two related samples of the average monthly revenues

\begin{tabular}{|c|c|c|c|c|c|c|c|c|c|}
\hline \\
\hline \multicolumn{10}{|c|}{ Alternative hypothesis: true mean of differences is not equal to 0} \\
\hline $\mathrm{N}$ & Mean & StDev & SE Mean & Corr & $95 \%$ Conf Interval & $t$ & $\mathrm{df}$ & p-value & Alt Hypothesis \\
\hline 10 & $-112500,00$ & 84697,17 & 26783,59 & 0,9648 & {$[-173088,70 ;-51911,29]$} & $-4,2003$ & 9 & 0,0023 & Accept \\
\hline
\end{tabular}

As shown in the table above, we have to reject the null hypotheses, concluding that there is a difference in the average monthly revenues before and after the loan or that the lending process of MFIs has been successful in increasing the average monthly revenues of enterprises served.

\subsubsection{The average annual revenues;}

There has also been recorded the average annual revenues before and after the loan for 10 business activities credited by MFIs, as they are shown in the table below; Using the Paired $t$-test calculations made with STATA we can test the hypotheses for comparing two related samples of the average annual revenues for MFIs clients before and after taking the loan, or if the MFIs lending process has been efficient or not in increasing the average annual revenues of business 
Table 4.14 Hypotheses testing for comparing two related samples of profit amount

\begin{tabular}{|c|c|c|c|c|c|c|c|c|c|}
\hline \multicolumn{10}{|c|}{ Alternative hypothesis: true mean of differences is not equal to 0} \\
\hline $\mathrm{N}$ & Mean & StDev & \begin{tabular}{|l|} 
SE Mean \\
\end{tabular} & Corr & 95\% Conf Interval & $\mathrm{t}$ & df & $p$-value & Alt Hypothesis \\
\hline 10 & $-53500,00$ & 62895,41 & 19889,27 & 0,9926 & {$[-98492,67 ;-8507,32]$} & $-2,6899$ & 9 & 0,0248 & \\
\hline
\end{tabular}

As shown in the table above, we have to reject the null hypotheses, concluding that there is a difference in the profit amount before and after the loan or that the lending process of MFIs has been efficient in increasing profit amount of the enterprises served.

\subsubsection{The profit margin;}

For the purpose of this study there has also been recorded the profit margin before and after the loan for 10 business activities credited by MFIs, as they are shown in the table below; Using the Paired $t$-test calculations made with STATA we can test the hypotheses for comparing two related samples of profit margin before and after the loan, or if the MFIs lending process has been efficient or not in increasing profit margin.

\begin{tabular}{l|c|c|c|c|c|c|c|c|c|c} 
Business activities & 1 & 2 & 3 & 4 & 5 & 6 & 7 & 8 & 9 & 10 \\
\hline Before loan & 10,0 & 5,0 & 7,5 & 15,0 & 15,0 & 12,0 & 20,0 & 20,0 & 9,0 & 22,0 \\
\hline After loan & 12,0 & 8,0 & 8,5 & 10,0 & 18,0 & 15,0 & 25,0 & 25,0 & 8,0 & 25,0
\end{tabular}

Table 4.15 Hypotheses testing for comparing two related samples of profit margin

\begin{tabular}{|c|c|c|c|c|c|c|c|c|c|}
\hline \multicolumn{10}{|c|}{ Paired T-Test of mean difference $=0$ versus not $=0$} \\
\hline \multicolumn{10}{|c|}{ Alternative hypothesis: true mean of differences is not equal to 0} \\
\hline $\mathrm{N}$ & Mean & StDev & SE Mean & Corr & 95\% Conf Interval & $\mathrm{t}$ & df & p-value & Alt Hypothesis \\
\hline 10 & $-1,9000$ & 2,9981 & 0,9481 & 0,9207 & {$[-4,0447 ; 0,2447]$} & $-2,0040$ & 9 & 0,0761 & Accept \\
\hline
\end{tabular}

As shown in the table above, we have to reject the null hypotheses, concluding that there is a difference in the profit margin before and after the loan or that the lending process of MFIs has been efficient in increasing profit margin of enterprises served.

\section{Awareness and Perception of Microfinance Institutions}

Analysis of the chart 5.1, revealed that 12 respondents constituting $8.0 \%$ are holding savings account on other MFIs, 50 respondents constituting 33.3\% are holding savings account on commercial banks, 59 respondents constituting 39.3\% are not holding savings account on any other financial institutions, and 29 respondents constituting 19.3\% are holding savings account on other financial institutions.

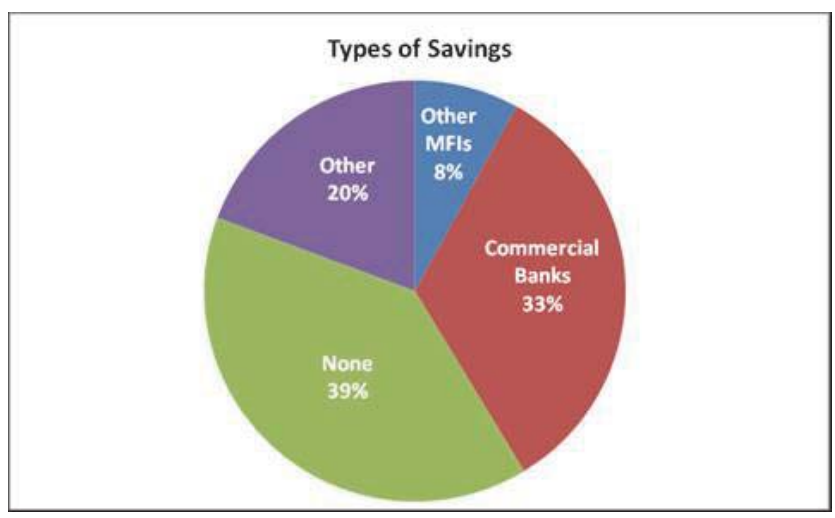

Chart 5.1 Classification of clients based on types of savings 
Based on the data provided, we see there is a great number of microfinance clients in Albania who not have any type of saving, showing that the microfinance market is still unconsolidated but it offers many potentials for improvements.

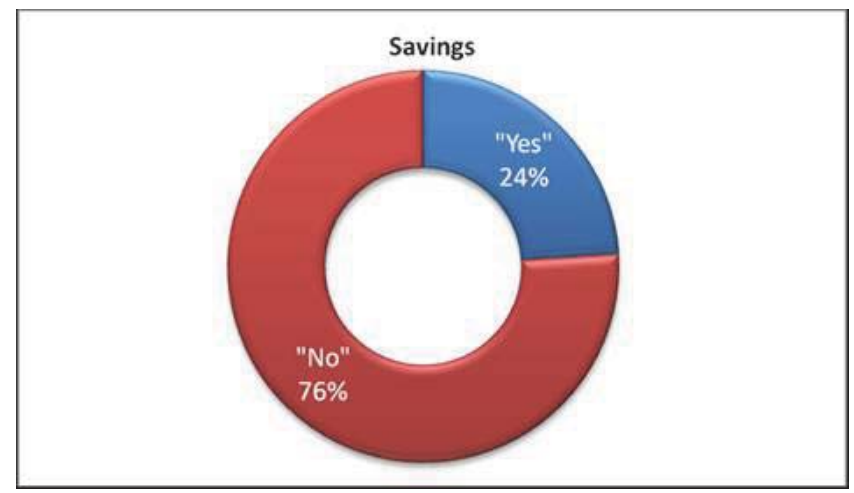

Chart 5.2 Classification of clients based on savings

Chart 5.2 indicates that the most of the respondents 114 (76.0\%) accepts the fact that they are not saving, which shows that the microfinance target group consist of low income people who are not capable of saving money for their future. Only $36(24.0 \%)$ of microfinance clients are actually saving.

As demand across the globe has continued to expand, the sector has seen more banks and other financial institutions open their services to the previously excluded. In 2010 , more than $61 \%$ of clients were served through a regulated bank or non-bank financial institution (representing $84 \%$ of loan portfolio) and nonprofit institutions represented approximately $42 \%$ of clients (36\% of portfolio).

According to the Microfinance Barometer 2012 - 3th Edition for the microfinance market, we have the figures worldwide;

$\Leftrightarrow 67 \%$ of borrowers served by a financial institution, and $33 \%$ by a non-profit institution.

$\Leftrightarrow 54 \%$ of institutions propose both credit and savings, $26 \%$ propose insurance products, and $54 \%$ propose nonfinancial services.

$\Leftrightarrow 38 \%$ of borrowers live in rural areas (rural lending represents $20 \%$ of the loan portfolio).

$\Leftrightarrow 73 \%$ of borrowers are women.

In developed countries as well, microfinance is increasingly being perceived as a potentially effective tool to counteract on the effects of the social and economic crisis. Supported by a favorable institutional environment, the sector is developing in Europe and in the U.S.

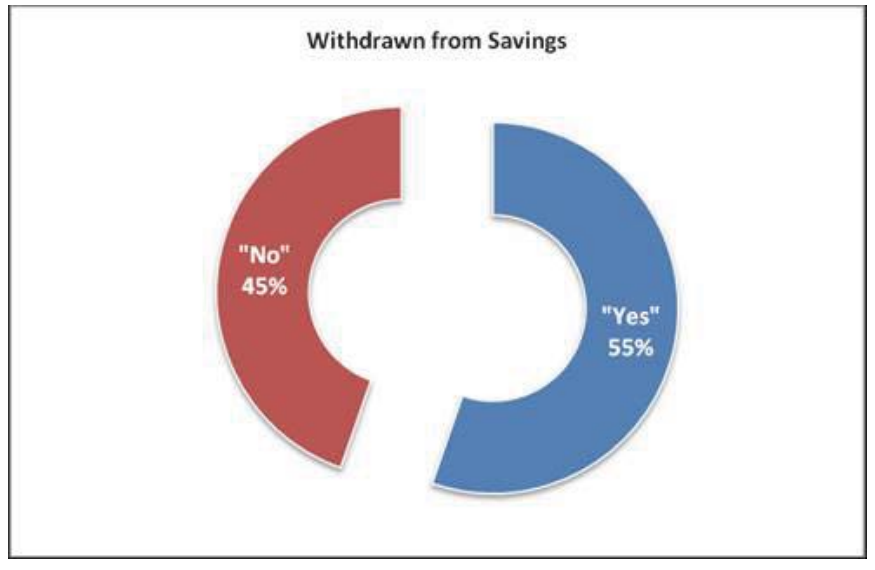

Chart 5.3 Classification of clients based on withdrawn from savings

Chart 5.3 indicates that most of the respondents 83 (55.3\%) admit that they are withdrawing from their saving, and 67 (44.7\%) of microfinance clients are not actually withdrawing from their saving. 


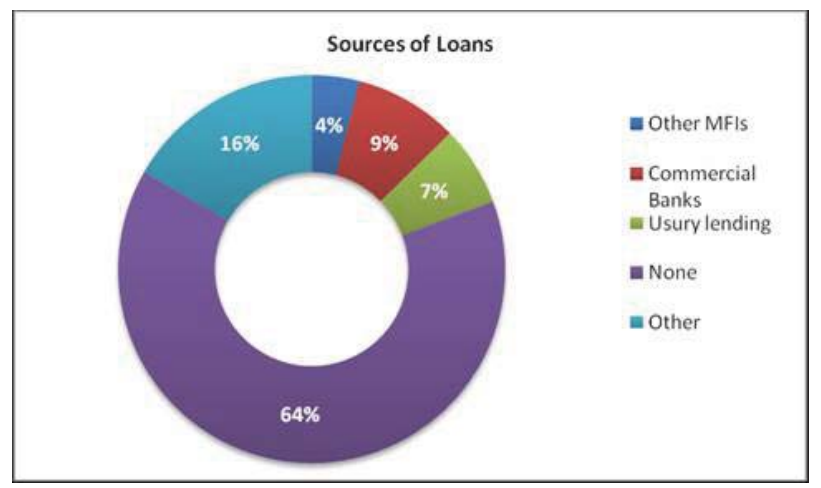

Chart 5.4 Classification of clients based on preference for credit

Chart 5.4 concludes that 6 respondents (4.0\%) are actually taking loans from other MFls, 13 respondents (8.7\%) are actually taking loans from commercial banks, 10 respondents (6.7\%) are actually taking other usury loans, 96 respondents (64.0\%) are not actually taking any loan and 25 respondents (16.7\%) are actually taking other loans.

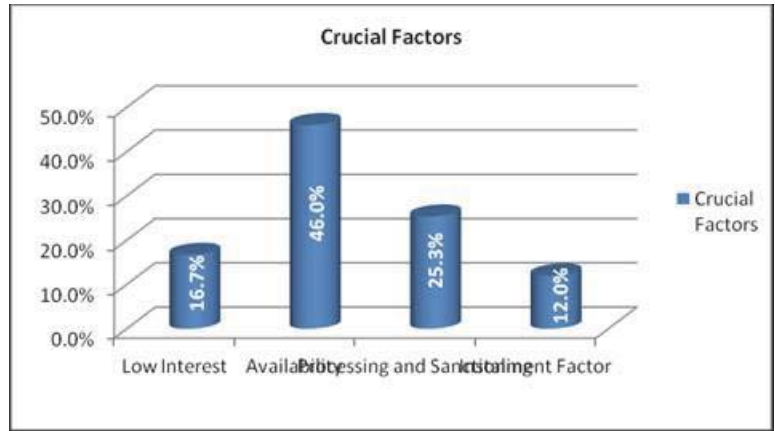

Chart 5.5 Classification of clients based on crucial factors

The findings of chart 5.5, reveal that $25(16.7 \%)$ out of 150 respondents believed the low interest rate is the crucial factor for the development of Microfinance Institutions. 69 (46.0\%) respondents understood that the availability of loan itself is very important for the development of Microfinance Institutions. 38 respondents (25.3\%) and 18 respondents (12.0\%) are of the opinion that the processing and sanctioning and installment factors are very much important for rapid growth of Microfinance Institutions.

Scanning the chart 5.6 we concluded that 115 respondents $(76.7 \%)$ share the view that the microfinance could lead to solving unemployment problem in the country and 35 respondents (23.3\%) assumed that the microfinance would not help in reducing unemployment problem in urban area.

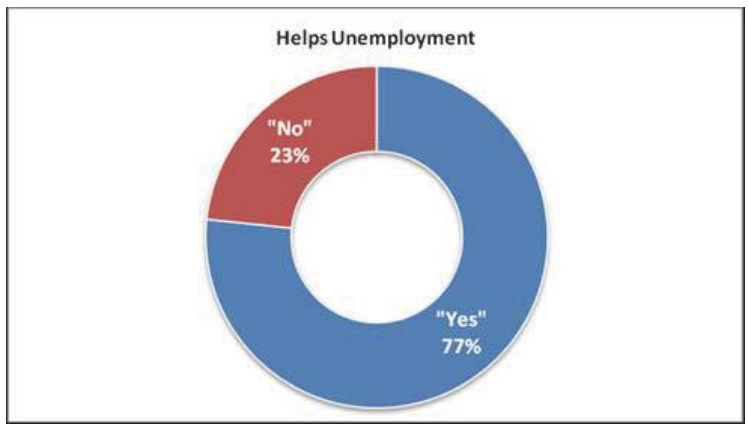

Chart 5.6 Classification of clients based on helping unemployment 
Studies in this field seem to establish a very favorable view of microfinance impact on employment creation and earnings of enterprises. MFIs activities are providing significant return to their clients meeting the objective of the microfinance institutions both in terms of livelihood improvements, poverty reduction, job creation, import substitutions and technology transfer.

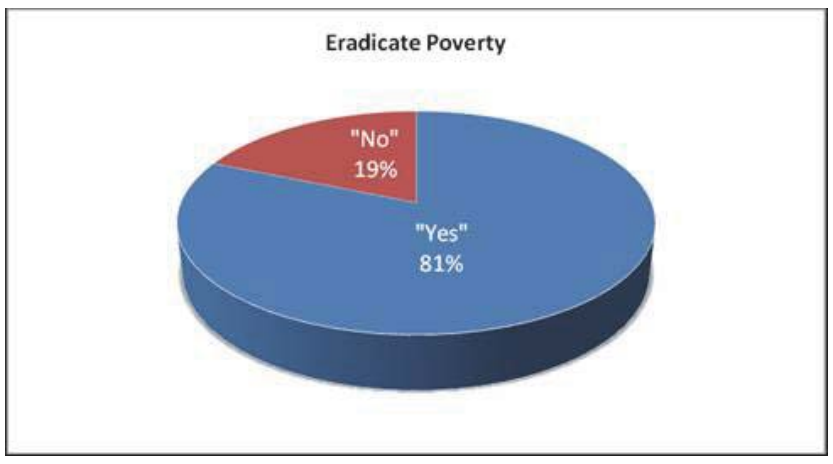

Chart 5.7 Classification of clients based on eradication of poverty

It is opined from the chart 5.7 that $122(81.3 \%)$ of the respondents alleged that microfinance could reduce poverty in the society whereas 28 respondents (18.7\%) of the total respondents do not think that the microfinance would wipe out poverty.

\section{Microfinance Role in Poverty Eradication}

\subsection{Food Security;}

Based on the data we can conclude that the clients and non-clients differ a lot in terms of food security. We can see that the figures are (38.60\% vs. 39.02\%) for "enough food, but not what we wanted". In the chart below we can also see the food security scale as according to the specific categories of differences.

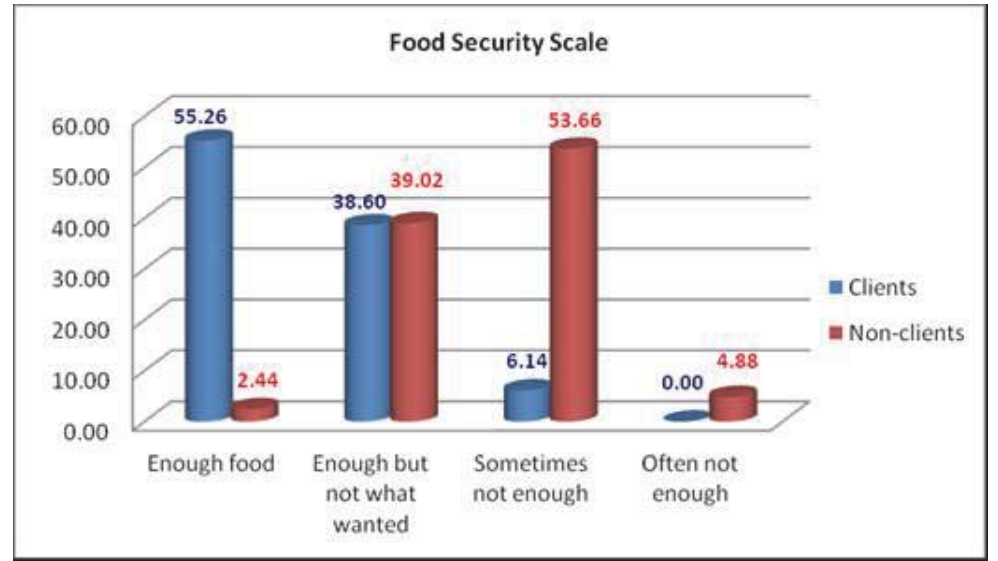

Chart 6.1 Food security scale

However, a higher percentage of the non-client group used gifts from family and friends to finance food purchases, whereas microfinance clients are much more likely to use micro-loans in purchasing food.

These results suggest a shift from reliance on gifts in purchasing food to use of micro-loans, and that program loans are used in financing food, and possibly other consumption needs. This find suggests that loans meet a variety of livelihood needs other than enterprise support. 


\subsection{Sickness and Disease;}

Including microfinance loans, there was a difference in the proportion of the client group and non-client group adopting any of the coping strategies to pay for health care costs, suggesting again that clients use micro-loans to finance consumption and emergency needs (22.33\% vs. $6.45 \%)$.

A number of widely used coping strategies include, in order or importance for client group compared to non-client group, current income (28.16\% vs. $16.13 \%)$, handouts from family or friends (6.80\% vs. $54.84 \%)$, selling assets (12.62\% vs. $32.26 \%)$, loans from family and friends ( $2.91 \%$ vs. $48.39 \%)$.

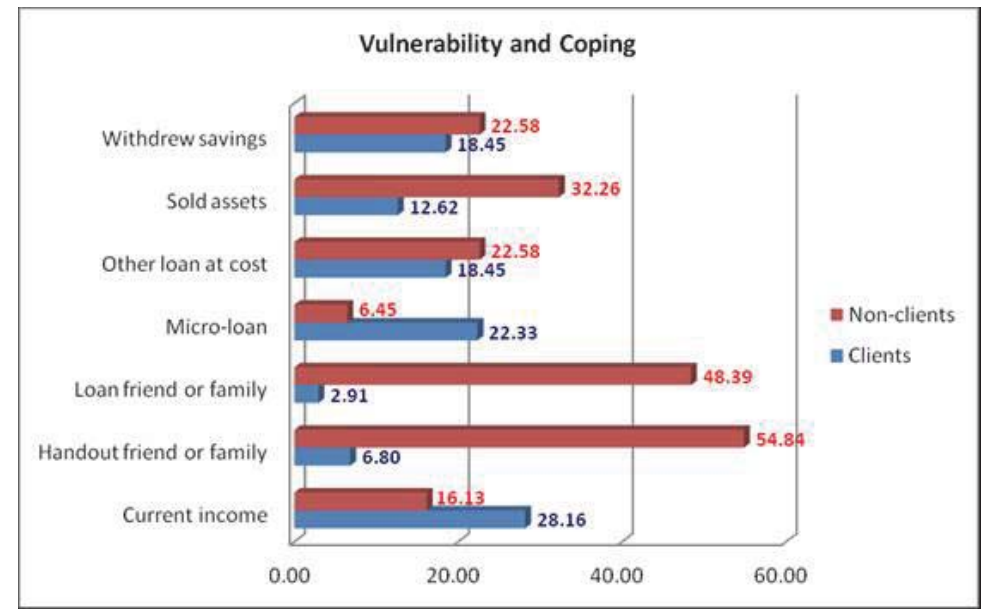

Chart 6.2 Vulnerability and coping

\subsection{Emergencies and Crises;}

Again, there was a difference in the proportion of the client and non-client group adopting any of the coping strategies to pay for unusually large or unexpected expenses. Primary coping mechanisms in non-client group were: handouts from family or friends $(20.22 \%)$, loans from family and friends (19.10\%), compared to the figures of $(8.65 \%)$ and $(1.92 \%)$ for the client group. While for the client group the primary coping strategies are current income $(25.00 \%)$, micro-loan (23.08\%), other loan at cost (13.46\%) compared to the figures of (5.62\%), (3.37\%) and (12.36\%) for the non-client group.

\section{Conclusions}

Based on these survey and observation results we can conclude that lending practices have a positive effect on entrepreneurial activities in increasing employee salaries, in job creation or generating employment, in increasing profit margin of enterprises served, as shown by the cases and models analyzed in the above text.

The research seems to bring a very admirable view of microfinance impact, undertaking and providing an excellent picture of the quality of MFIs lending as well as some quantitative information related to employment creation and earnings of enterprises. MFIs activities are providing significant return to their clients meeting the objective of the microfinance institutions both in terms of livelihood improvements, poverty reduction, job creation, import substitutions and technology transfer.

It's true that the most important finding during the last two decades in the world of microfinance did not come from the world of the rich or the relatively well off. It has come from the countries that encourage microfinance. Microfinance grants facilitating a small firm that startup capital which is necessary to sell. It is urged that government also necessitate the banks to provide microfinance loan to tiny business and enterprises.

Many innovative and socially conscious banking institutions are entering the microfinance market in Albania on their own, because of the growth opportunities. Recently, microfinance seekers not only are highly motivated to repay the loans but their success also spurs others to seek loan. Microfinance is arguably the most innovative strategy to address the problem of global and national poverty. It is the practice of offering small, collateral free loans which otherwise would 
not have access to the capital which is necessary to begin a small business or other income generating activities. It has been observed that microfinance institutions are not only significantly contributing to the development of finance sector in Albania, but also they playing an important role to eradicate poverty by providing much needed capital to low income people who are able to generate remarkable return on the investment.

There is evidence that becoming a microfinance client is associated with greater food security relative to nonparticipants, and so there is evidence that clients use program loans to meet current consumption needs and appear to be transitioning from a reliance on handouts to the utilization of loans to meet associated cash flow needs (possibly an indication of greater self-reliance). Although programme loans are intended to be used for consumption purposes, such use can be considered a benefit of program participation, providing clients with an important coping mechanism to meet cash flow needs associated with consumption.

Facts verify the conclusion that the Albanian MFIs lending activities is a very commendable undertaking and provides an excellent picture of the quality of MFIs lending as well as some quantitative information related to employment creation and earnings of enterprises. MFI activities are providing significant return to their clients, meeting the objective of the microfinance companies both in terms of livelihood improvements, poverty reduction, job creation, import substitutions and technology transfer.

MFIs are often pressurized to bring down interest rates to unreasonable levels in the name of service to the poor without provision of any support. MFIs have to charge interest rates on loans to fully cover cost of funds, operational costs, loan loss provisions and reasonable margin of profit for servicing equity and building sustainability.

MFIs should follow a rational and transparent interest policy to avoid suspicions and encourage professionalism in the sector. MFIs may take steps to rationalize the cost of funds by accessing various sources of funds, increasing operational efficiency, involving local small NGOs, etc.

Borrowers are often unaware of the effective cost of borrowing and complain about the high cost of loan and lack of transparency. MFIs should be transparent with respect to interest rate and other costs charged and effective cost of credit to the borrowers.

\section{References}

Armendáriz B., University College London, UK \& Harvard University, USA and LABIE M. Université de Mons, Belgium - The handbook of microfinance, 2011

Ashta A. - Advanced Technologies for Microfinance: Solutions and Challenges, Groupe ESC Dijon Bourgogne, France, 2011

Bateman M. - Why doesn't microfinance work? - the destructive rise of local neoliberalism, 2010

Baumann T. - Microfinance and Poverty Alleviation in South Africa, August 2001

Belegu K. - Dissertation, "Microfinance Institutions and their Contribution on the Reduction of Poverty in Rural Albania" (AGR/01) 2010

Ceku Bardhyl - Drejtim Marketingu, SHBLU, Tiranë 2010

Ceku Bardhyl, Kola Forcim, "Metoda Kërkimi", Tirane, 2011.

Copestake, J. B., Halotra, S., Johnson, S., "Assessing the Impact of Microcredit: A Zambia Case Study", Journal of Development Studies, 37(4), 81-100, 2001/ May 2012

Dunn, E., (2005), Impact of Microcredit on Clients in Bosnia and Herzegovina, Presented to Foundation for Sustainable Development of the Federation of Bosnia and Herzegovina and Republika Srpska Development and Employment Foundation, May, 2005. http://www.european-microfinance.org/ data/file/benchmark/ Impacts_of_microcredit_on_clients_in_BiH.pdf/ September 2012

hbr.harvardbusiness.org/ May 2012

http://www.worldbank.org/ July 2012

Hulme David, Arun Thankom, Microfinance, 2009

Kamal, M. M. (1999), Measuring Transformation: Assessing and Improving the Impact of Microcredit, Discussion Paper, Impact Evaluation Mechanism, Association for Social Advancement (ASA), Dhaka, Bangladesh. http://www.microcreditsummit.org/ papers/impactpaper3H.htm/ September 2012

Kola Forcim, "Microcredit contribution on social wellbeing", "LAPLAMBERT Academic Publishing", AMAZON.com, ISBN-13: 9783843354110, Germany, 15 September 2010.

Kola Forcim, Korsita Bajram, "Microcredit role in the sustainable development and social wellbeing" co-author, published: The first International Scientific Conference of the Social Work programme at the University of Mostar, Bosnia and Herzegovina, October 2010.

Kola Forcim, Korsita Bajram, Abazi Arjan, "Does microcredit creates social and economic development" co-author, published: The first International Scientific Conference, "Local Sustainable Development - challenges and opportunities", University of Pejë, Kosovë, June 2011.

Latifee, H. I. (2003), Microcredit and Poverty Reduction, International Conference on Poverty Reduction through Microcredit. TaksimIstambul, June 09-10, 2003. http://www.grameentrust.org/Microcredit\%20and\%20Poverty\%20Reduction\%20June\%202003 \%20in\%20TurkeyF.pdf/ July 2012 
Mamun, Abdullah-Al-, Abdul Wahab, Sazali and Malarvizhi, C.Al, Impact of Amahah Ikhtiar Malaysia's Microcredit Schemes on Microenterprise Assets in Malaysia (July 1, 2010). International Research Journal of Finance and Economics, no. 60, pp.144154, 2010./ October 2012

Mosley, Paul (1996), Metamorphosis from NGO to Commercial Bank: The Case of Bancosol in Bolivia. In Finance Against Poverty, Volume II: Country Case Studies, edited by David Hulme and Paul Mosley, 1-45. London: Routledge./ September 2012

Panda K. D. (2009), Participation in the Group Based Microfinance and its Impact on Rural Households: A Quasi-experimental Evidence from an Indian State, Global Journal of Finance and Management, Vol: 1, No: 2, Pp: 171-183/ August 2012

Rahman, S., Rafiq, R. B. and Momen, M. A. (2009). Impact of Microcredit Programs on Higher Income Borrowers: Evidence from Bangladesh. International Business \& Economics Research Journal, Vol-:8, Issue: 2 http://journals.cluteonline.com/ index.php/IBER/article/view/3109/3157/ June 2012

Sebstad, J and Walsh, M. (1991), Microenterprise Credit and its Effects in Kenya: An Exploratory Study, Report prepared for USAID AFR/MDI and S\&T/WID. Coopers and Lybrand, Washington, D.C http://pdf.usaid.gov/pdf_docs/PNABL231.pdf / August 2012

www.ifad.org/ April 2013

www.ilo.org/ July 2013

www.insee.fr/ June 2013

www.microjournal.com/ June 2013

www.mixmarket.org/ August 2013

Yenawine B. H. and costello M. R. - Benjamin Franklin and the invention of microfinance, 2010

Yunus M. - Creating a World Without Poverty; Social Business and the Future of Capitalism, 2007 
